\title{
Differential effects of oestradiol and progesterone on proliferation and morphology of cultured bovine uterine epithelial and stromal cells
}

\author{
C. W. Xiao and A. K. Goff* \\ Centre de Recherche en Reproduction Animale, Faculté de médecine vétérinaire, Université de Montréal, \\ 3200 Rue Sicotte, St-Hyacinthe, Quebec J2S 7C6, Canada
}

\begin{abstract}
The effect of oestrogen and progesterone on the proliferation of cultured bovine uterine epithelial and stromal cells was assessed. Epithelial and stromal cells recovered from cows at day 1 to day 3 of the oestrous cycle were cultured in RPMI medium supplemented with $5 \%$ steroid-free fetal calf serum for 4 and 8 days. The addition of progesterone to the culture medium altered the morphology of stromal cells. Oestradiol $\left(0.1-10 \mathrm{nmol} \mathrm{l}^{-1}\right)$ and progesterone $\left(50 \mathrm{nmol} \mathrm{l}^{-1}\right.$ ) significantly increased the total DNA (from $9.6 \pm 0.96$ to $25.6 \pm 0.99 \mu \mathrm{g}$ per well, $P<0.001$ ) and protein content (from $76.6 \pm 2.6$ to $125.8 \pm 2.6 \mu \mathrm{g}$ per well, $P<0.001$ ) and decreased the ratio of protein to DNA (from $8.0 \pm 0.24$ to $4.9 \pm 0.24, P<0.01$ ) in stromal cells during the first 4 days. During the second 4 days, the relative percentages of increase in DNA content were not affected by steroids, indicating that the major effect of steroids on stromal cell proliferation was exerted during the first 4 days of incubation. The morphology of epithelial cells was not influenced by the addition of steroids. DNA content of epithelial cells was reduced by the addition of oestrogen (from $22.9 \pm 2.1$ to $15.0 \pm 2.0 \mu \mathrm{g}$ per well, $P<0.01$ ), but not progesterone (from $22.9 \pm 2.1$ to $25.8 \pm 2.0 \mu \mathrm{g}$ per well, $P>0.05$ ). Total protein content of epithelial cells was reduced by oestradiol by day 4 (from $111.0 \pm 6.2$ to $71.0 \pm 6.2 \mu$ g per well, $P<0.01$ ), but not by day 8 (from $305.0 \pm 10.5$ to $296.0 \pm 10.5 \mu \mathrm{g}$ per well, $P>0.05$ ). Progesterone increased the total protein content (from $305.0 \pm 10.5$ to $366.0 \pm 10.5 \mu \mathrm{g}$ per well, $P<0.01$ ). Oestradiol significantly enhanced the ratio of protein to DNA in epithelial cells at day 8 (from $10.1 \pm 1.0$ to $16.8 \pm 1.0, P<0.01$ ). These results show that oestradiol and progesterone have different effects on the proliferation and morphology of epithelial and stromal cells in vitro.
\end{abstract}

\section{Introduction}

The endometrium undergoes major histological and biochemical changes during the oestrous cycle. These changes are induced by progesterone and oestradiol and are necessary to provide a suitable environment for embryo development in the pregnant animal. There are marked morphological changes in the endometrium, such as an increase in the thickness and growth of the glands during the oestrous cycle in ruminants (Nalbandov, 1976). Progesterone and oestradiol are also responsible for maintaining synchrony between the embryo and the endometrium (Wilmut et al., 1985) and play an important role in regulating prostaglandin release at luteolysis (McCracken et al., 1984; Lafrance and Goff, 1988). Understanding the mechanisms involved in the action of progesterone and oestradiol in these processes is difficult due to the complexity of the interactions involved.

Recent work in sheep has shown that growth of epithelial and stromal cells is correlated with systemic concentrations of progesterone and oestradiol (Johnson et al., 1997). The

${ }^{*}$ Correspondence.

Received 22 May 1997 proliferation and differentiation of uterine epithelial and stromal cells are controlled primarily by oestradiol and progesterone (Conti et al., 1981; Irwin et al., 1991; Watson et al., 1994). However, the growth and differentiation responses to these hormones in the different endometrial cell types are not yet fully understood. Furthermore, the effect of oestradiol and progesterone on uterine endometrial proliferation observed in vitro is inconsistent and depends on experimental conditions, such as the presence of serum and the purity of the isolated cell population. Oestradiol, progesterone or their combination stimulate the growth of human endometrial cells (Pavlik and Katzenellenbogen, 1978) and isolated stromal cells (Irwin et al., 1991) cultured in the presence of a steroid-free calf serum. In combination, but not separately, oestradiol and progesterone significantly increased $\left.{ }^{3} \mathrm{H}\right]$ thymidine incorporation by human endometrial stromal cells in serum-free medium (Chegini et al., 1992). A lack of effect by oestradiol and progesterone on the proliferation of endometrial, epithelial and stromal cells from rodents and humans has been reported (Iguchi et al., 1983; Tomooka and McLachlan, 1986; Irwin et al., 1989; Chegini et al., 1992; Rossi et al., 1992). It has been suggested that this lack of oestradiol may be due to the absence of growth factors, 
such as insulin (Van der Burg et al., 1988), insulin-related polypeptides (Murphy et al., 1987) and epidermal growth factor (Mukku and Stancel, 1985; Di Augustine et al., 1988). These factors are considered to be potential mediators of oestrogen-induced proliferation. Inhibitory effects of oestrogen on the proliferation of guinea-pig (Alkhalaf et al., 1991) and human (Marshburn et al., 1994) endometrial glandular epithelium have also been reported.

We have previously shown that progesterone and oestradiol can alter prostaglandin secretion from epithelial and stromal cells isolated from bovine endometria (Bergeron and Goff, 1993; Asselin et al., 1996). However, little information is available on the effect of these hormones on bovine endometrial cell proliferation. Although oestradiol is uterotropic in vivo, no effect of oestradiol has been observed on the growth of bovine endometrial cells in vitro (Tiemann et al., 1994; Asselin and Fortier, 1996). The objective of the study reported here was to determine if oestradiol and progesterone are able to alter the DNA and protein content of endometrial stromal and epithelial cells grown in vitro.

\section{Materials and Methods}

\section{Chemicals and reagents}

Tissue culture medium (RPMI 1640), Hank's Buffered Saline Solution (HBSS, calcium and magnesium free), fetal calf serum (FCS), antibiotics and Trypan blue were purchased from Gibco (Grand Island, NY). Collagenase (Type II), trypsin (Type III, from bovine pancreas), DNase I (Type I, from bovine pancreas), gentamicin, calf thymus DNA, Hoechst No. 33258, BSA, oestradiol, progesterone and goat anti-mouse immunoglobulin $G$ (IgG) conjugated to fluorescein isothiocyanate (FITC) were purchased from Sigma Chemical Co. (St Louis, MO). Monoclonal antibodies to cytokeratin (No. 18) and fibronectin were obtained from Boehringer (Mannheim). Matri-gel was obtained from VWR Scientific (Ontario). Bio-Rad protein assay-dye reagent concentrate was obtained from Bio-Rad Laboratories (Mississauga, Ontario).

\section{Preparation and culture of cells}

Bovine uteri from cows at day 1 to day 3 of the oestrous cycle were collected at an abattoir and transported on ice to the laboratory. Days 1-3 were selected because the stage of oestrus can be determined accurately from slaughterhouse material owing to the presence of the corpus haemorrhagicum in the ovary and, thus, variability among uterine samples is reduced. The endometrial epithelial and stromal cells were separated by a modification of the procedure described by Fortier et al. (1988). Briefly, the two horns of the uterus were placed in sterile HBSS containing $10 \mu \mathrm{l}$ antibiotics $\mathrm{ml}^{-1}$ (100 units of penicillin, $100 \mu \mathrm{g}$ of streptomycin and $0.25 \mu \mathrm{g}$ of amphotericin B). The myometrial layers were dissected from the two horns, and the remaining endometrial tissue was then everted to expose the epithelium. The everted horns were first digested for $2 \mathrm{~h}$ in HBSS with $0.3 \%(\mathrm{w} / \mathrm{v})$ trypsin at room temperature to obtain epithelial cells. At the end of incubation, the digested horns were scraped slightly with forceps and washed twice in HBSS. The cells from the digestion and washings were pooled and FCS was added ( $10 \%$ final volume) to block the action of trypsin. The horns were then further digested to obtain stromal cells by incubating in HBSS with $0.064 \%(\mathrm{w} / \mathrm{v})$ trypsin III, $0.064 \%(\mathrm{w} / \mathrm{v})$ collagenase II and $0.032 \%(\mathrm{w} / \mathrm{v})$ DNase I for $45 \mathrm{~min}$ at $37^{\circ} \mathrm{C}$. FCS was added $(10 \%$ final volume) to block the action of trypsin at the end of incubation.

Epithelial cells. Most of the epithelial cells were in clumps after trypsin digestion. Therefore, it was possible to separate them from single stromal cells by low-speed centrifugation $(60 \mathrm{~g}$ for $5 \mathrm{~min}$ ). The centrifugation pellet was then washed three more times with HBSS. The epithelial cells were purified further by suspension in $20 \mathrm{ml}$ RPMl medium supplemented with $5 \% \mathrm{FCS}$ and $50 \mathrm{\mu g} \mathrm{ml}^{-1}$ of gentamicin and plated onto $100 \mathrm{~mm} \times 20 \mathrm{~mm}$ Petri dishes (Nunclon, Grand Island, NY) and incubated at $37^{\circ} \mathrm{C}$ with $5 \% \mathrm{CO}_{2}, 95 \%$ air for $3 \mathrm{~h}$. At the end of the incubation, any contaminating stromal cells that had adhered to the dish and the floating epithelial cells were collected. The cells were counted and their viability determined by Trypan blue exclusion. At this stage $>95 \%$ of cells were viable. The epithelial cells were then plated onto Matri-gel coated six-well plates at a concentration of $5 \times 10^{5}$ cells per well (Corning, NY). Since the epithelial cells took about $48 \mathrm{~h}$ to attach to the plates, they were cultured for 4 more days in RPMI-1640 medium containing 5\% FCS that had been depleted of steroids by dextran-charcoal extraction at $37^{\circ} \mathrm{C}$ in humidified air $\left(5 \% \mathrm{CO}_{2}\right)$. The cells were then cultured for 4 or 8 days in the presence or absence of various concentrations of oestradiol and progesterone.

Stromal cells. The cell suspension of stromal cells was centrifuged at $60 \mathrm{~g}$ for $5 \mathrm{~min}$ to remove cell clumps and the supernatant was then centrifuged at $1000 \mathrm{~g}$ for $10 \mathrm{~min}$. The pelleted stromal cells were washed twice with HBSS and plated onto six-well plates at a concentration of $2 \times 10^{6}$ cells per well and incubated for $3 \mathrm{~h}$. The floating cells were washed away by gentle pipetting. The attached stromal cells were then cultured in RPMI-1640 medium containing 5\% FCS, which was depleted of steroids by dextran-charcoal extraction, in the presence or absence of various concentrations of oestradiol and progesterone. At the time of plating, the viability of the stromal cells was $>95 \%$.

\section{Cell proliferation experiment}

All cells were cultured in phenol red-free RPMI-1640 medium containing 5\% FCS (depleted of steroids by dextrancharcoal extraction) in the presence or absence of steroids at $37^{\circ} \mathrm{C}$ in humidified air $\left(5 \% \mathrm{CO}_{2}\right)$. The charcoal extraction procedure decreased added $\left[{ }^{3} \mathrm{H}\right]$ oestradiol $\left(25 \mathrm{pg} \mathrm{m}^{-1}\right)$ by at least $100-$ fold. The stromal and epithelial cells had reached about $60 \%$ confluency at the beginning of culture. Cells were cultured for 4 or 8 days in medium alone or in medium containing oestradiol $\left(0.1,1\right.$ or $\left.10 \mathrm{nmol} \mathrm{l^{-1 }}\right)$, progesterone $\left(50 \mathrm{nmol} \mathrm{l}^{-1}\right)$ or oestradiol $\left(1 \mathrm{nmol} \mathrm{l^{-1 }}\right)$ plus progesterone $\left(50 \mathrm{nmol} \mathrm{l}{ }^{-1}\right)$. The medium was changed every 2 days. The 4- and 8-day culture periods presented in the results represent the time the cells were exposed to the hormone treatment. 


\section{Determination of DNA content}

At the end of the culture period, the medium was removed and the cells were rinsed twice with HBSS and then detached with $1 \mathrm{mmol}$ EDTA $\mathrm{I}^{-1}$ in HBSS and the use of a rubber scraper. Cells were pelleted by centrifuging at $1000 \mathrm{~g}$ for $5 \mathrm{~min}$, and $100 \mu \mathrm{l}$ of $0.2 \%(\mathrm{w} / \mathrm{v})$ SDS in ETN buffer $(10 \mathrm{mmol}$ $1^{-1}$ EDTA, $10 \mathrm{mmol} 1^{-1}$ Tris- $\mathrm{HCl}, 100 \mathrm{mmol}^{-1} \mathrm{NaCl}$, $\mathrm{pH}$ 7.0) was added to the pellet. The pellet was sonified 10 times for stromal cells and 15 times for epithelial cells using a Branson sonifier-450 (VWR Scientific, Ontario) at 10\% power. The DNA content in $10 \mu \mathrm{l}$ sonified cell suspension was determined using the bisbenzimide fluorescent dye method of Labarca and Paigen (1980). Calf thymus DNA was used as standard at concentrations of $4,8,16,32,64,128$ and $250 \mathrm{ng} \mathrm{ml}^{-1}$. In some experiments $(n=3)$, the numbers of cells were counted after detachment from the culture dish, and a linear relationship between the number of cells and the DNA content was observed $\left(y=(35+179.8 x) 10^{3}, r^{2}=0.999\right.$, where $y$ is the number of cells and $x$ is the DNA content $(\mu \mathrm{g}))$.

\section{Immunocytochemistry}

Homogeneity of the cells was examined by indirect immunofluorescent staining for specific markers of epithelial cells (cytokeratin) and stromal cells (fibronectin). Cells were cultured in 24-well plates, washed with PBS and fixed using $2 \%$ formaldehyde in PBS for $15 \mathrm{~min}$ at room temperature. The cells were permeabilized by treatment with $0.5 \%$ Triton-X100 overnight, rinsed with PBS and then incubated for $\mathrm{Ih}$ with either anticytokeratin or antifibronectin at a concentration of $10 \mu \mathrm{g} \mathrm{ml}^{-1}$. Negative controls were incubated with bovine serum. The cells were washed with PBS and incubated with the second antibody, goat anti-mouse IgG conjugated to FITC, for $1 \mathrm{~h}$ at $37^{\circ} \mathrm{C}$. The slides were examined with a Universel Zeiss epifluorescence microscope.

\section{Measurement of total protein}

Total protein was measured in $10 \mu \mathrm{l}$ of sonified cell suspension using the Bradford method (Bio-Rad Laboratories). BSA was used as standard ( 0.0875 to $1.4 \mathrm{mg} \mathrm{ml}^{-1}$ ).

\section{Statistical analyses}

Each treatment was carried out in triplicate using the cells from one uterus and each experiment was repeated with 6-10 different uteri. The effects of treatment on DNA content and on the ratio of total protein to DNA content of uterine cells were evaluated by least-squares analysis of variance. Treatments were analysed in multifactorial design (ANOVA) which included the main effects of experiments, cell type, duration of culture and hormone treatments, and the appropriate interactions. Simple linear contrasts were used to determine differences between individual means. All differences were considered significant at $P<0.05$.

\section{Results}

\section{Effect of oestradiol and progesterone on cell morphology}

Clumps of epithelial cells attached to the culture surface as small colonies within $48 \mathrm{~h}$, and were polygonal or spherical in shape. When incubation time was extended, the cells became a monolayer and exhibited cuboidal or columnar morphology characteristic of epithelial cells (Fig. Ia). Stromal cells presented a monolayer of flat, spindle- and fibroblast-like cells. The homogeneity of the cell populations was examined by immunocytochemistry. Epithelial cell contamination of stromal cells was about $3 \%$ and stromal cell contamination of epithelial cells was less than $1 \%$ (Fig. 1).

The effect of oestradiol and progesterone on the morphology of epithelial and stromal cells was evaluated after 4 days of culture. The general pattern of growth was observed using an inverted phase-contrast microscope. Neither oestradiol nor progesterone treatment resulted in a change in the appearance of the epithelial cells. The morphology of the stromal cells was not altered by oestradiol at the different concentrations used. However, progesterone $\left(50 \mathrm{nmol} \mathrm{l}^{-1}\right)$ and the combination of progesterone $\left(50 \mathrm{nmol} \mathrm{l}^{-1}\right)$ plus oestradiol ( $1 \mathrm{nmol} \mathrm{l^{-1 }}$ ) significantly changed the morphology of stromal cells (Fig. 2). Instead of the homogeneous distribution of cells seen in control or oestradiol-treated groups (Fig. 2a, b), the progesterone-treated cells migrated together to form many star-shaped colonies (Fig. 2c). The appearance of these colonies was more dense (Fig. $2 \mathrm{~d}$ ) in the oestradiol plus progesterone treatment group than in the progesterone alone treatment group.

\section{Effect of oestradiol and progesterone on the DNA and protein content} of stromal cells

Both oestradiol and progesterone significantly stimulated proliferation of stromal cells after incubation for 4 days $(P<0.001)$ (Fig. 3a). The effect of oestradiol was dose dependent with the maximum dose being between 1 and $10 \mathrm{nmol}$ $1^{-1}$. Progesterone stimulated DNA content to a greater degree than oestradiol $(P<0.001)$ and the effect of progesterone was not modified by oestradiol, indicating no interaction between these two hormones.

The total protein content of stromal cells measured after 4 days of incubation followed the same pattern as the DNA content (Fig. 3b). The stimulating effect of oestradiol was dose dependent and there were no differences among the treatments of $10 \mathrm{nmol}$ oestradiol $\mathrm{l}^{-1}, 50 \mathrm{nmol}$ progesterone $\mathrm{I}^{-1}$ and $1 \mathrm{nmol}$ oestradiol $\mathrm{I}^{-1}$ plus $50 \mathrm{nmol}$ progesterone $\mathrm{l}^{-1}$. Oestradiol and progesterone significantly decreased the ratio of total protein to DNA content $(P<0.05$, Fig. $3 \mathrm{c})$. The ratio declined $19 \%, 29 \%, 25 \%, 36 \%$ and $39 \%$ for cells treated with $0.1,1$, $10 \mathrm{nmol}$ oestradiol $\mathrm{I}^{-1}, 50 \mathrm{nmol}$ progesterone $\mathrm{I}^{-1}$, and $1 \mathrm{nmol}$ oestradiol $1^{-1}$ plus $50 \mathrm{nmol}$ progesterone $\mathrm{l}^{-1}$, respectively.

The effects of hormone treatment and duration of culture on cell growth were highly significant $(P<0.0001)$, and there was an interaction between treatments and duration $(P<0.01)$ for DNA content, protein content, and protein to DNA ratio (Fig. 4). In medium alone, the DNA content of stromal cells increased $34.4 \%$ within the following 4 days $(P<0.01)$ (Fig. 4a). Although the absolute increases in DNA content (value at day 8 minus value at day 4 ) during the second 4 days of culture $\left(5.4,7.6,6.2 \mu \mathrm{g}\right.$ per well, for $1 \mathrm{nmol}$ oestradiol $1^{-1}$, $50 \mathrm{nmol}$ progesterone $1^{-1}$, and $1 \mathrm{nmol}$ oestradiol $\mathrm{I}^{-1}$ plus $50 \mathrm{nmol}$ progesterone $\mathrm{I}^{-1}$, respectively) were higher than that 

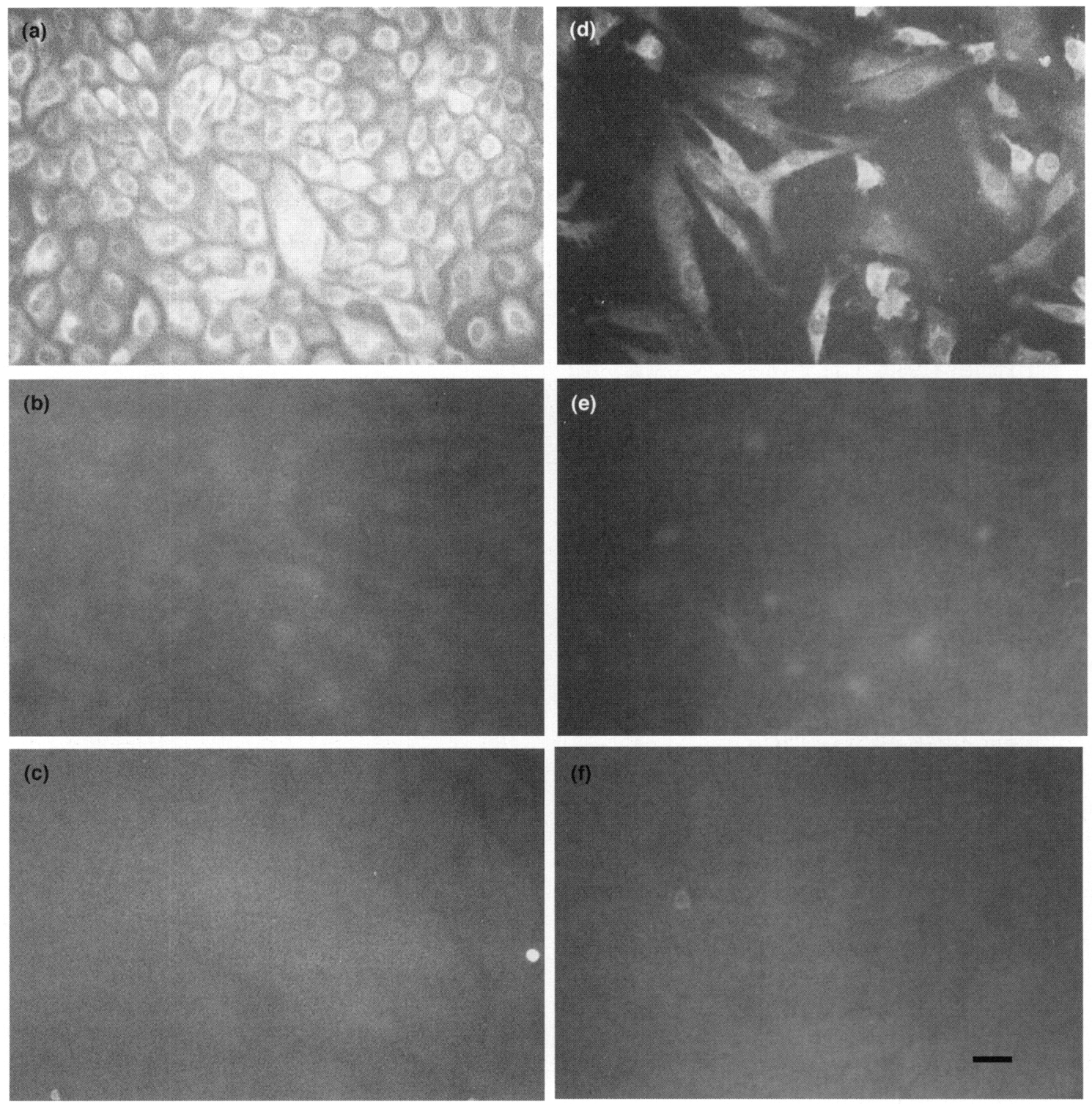

Fig. 1. Immunofluorescent staining of purified bovine epithelial and stromal cells. Epithelial cells were stained with anticytokeratin (a), but not with antifibronectin (b) or non-immune serum (c). Stromal cells were stained with antifibronectin (d), but not with anticytokeratin (c) or non-immune serum (f). Scale bar represents $25 \mu \mathrm{m}$.

of the control $(3.3 \mu \mathrm{g}$ per well), the relative increase in DNA (the increase in DNA between days 4 and 8 expressed as a percentage of the content at day 4) of the hormone-treated cells decreased when compared with the control $(34.4 \%, 28.9 \%$, $30.9 \%$ and $24.2 \%$, for control, $1 \mathrm{nmol}$ oestradiol $1^{-1}, 50 \mathrm{nmol}$ progesterone $\mathrm{I}^{-1}$, and $\mathrm{I}$ nmol oestradiol $\mathrm{I}^{-1}$ plus $50 \mathrm{nmol}$ progesterone $\mathrm{I}^{-1}$, respectively). This result indicated that DNA synthesis had slowed during the second 4 days of culture and that oestrogen and progesterone were less effective in stimulating DNA synthesis during this time. In contrast to the change in DNA content, oestradiol and progesterone increased both the absolute $(44,81,88,104 \mu \mathrm{g}$ per well for control, I nmol oestradiol $I^{-1}, 50 \mathrm{nmol}$ progesterone $\mathrm{I}^{-1}$, and $1 \mathrm{nmol}$ oestradiol $1^{-1}$ plus $50 \mathrm{nmol}$ progesterone $1^{-1}$, respectively) and the relative protein content in stromal cells $58 \%$, $76 \%, 70 \%$, and $82 \%$ for control, 1 nmol oestradiol $1^{-1}, 50 \mathrm{nmol}$ progesterone $1^{-1}$, and 1 nmol oestradiol $1^{-1}$ plus $50 \mathrm{nmol}$ progesterone $1^{-1}$, respectively). At day 8 , the ratios of total protein to DNA content increased significantly compared with those at day $4(17.5,36.8,31.4$, and 46.9 for control, 1 nmol oestradiol $1^{-1}, 50 \mathrm{nmol}$ progesterone $\mathrm{I}^{-1}$, and $1 \mathrm{nmol}$ oestradiol $\mathrm{I}^{-1}$ plus $50 \mathrm{nmol}$ progesterone $\mathrm{I}^{-1}$, respectively, Fig. 4c). Thus, the effect of hormone treatment on the protein content of the cells was enhanced with the extended incubation time.

Effect of oestradiol and progesterone on the DNA and protem content of epithelial cells

Treatment with oestradiol alone inhibited the proliferation of endometrial epithelial cells in a dose-dependent manner 

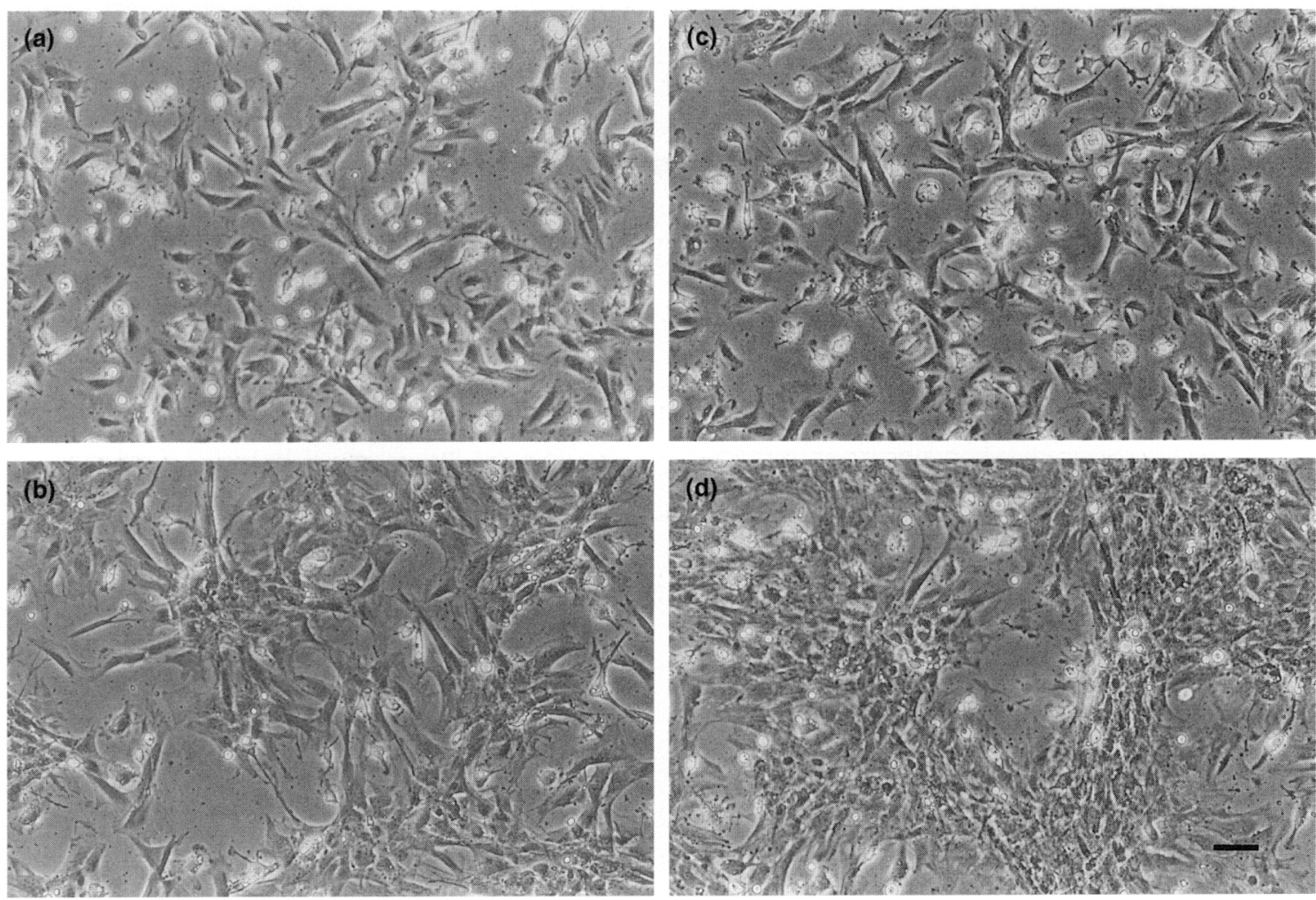

Fig. 2. Influence of oestradiol and progesterone on the morphology of bovine endometrial stromal cells. Stromal cells were cultured in RPMI medium supplemented with $5 \%$ steroid-free fetal calf serum (a) alone, or in presence of (b) $10 \mathrm{nmol}$ oestradiol $l^{-1}$, (c) $50 \mathrm{nmol}$ progesterone $\mathrm{l}^{-1}$, or (d) $10 \mathrm{nmol}$ oestradiol $\mathrm{l}^{-1}$ plus $50 \mathrm{nmol}$ progesterone $\mathrm{l}^{-1}$ for 4 days. The photographs were taken using an inverted phase contrast microscope. Scale bar represents $50 \mu \mathrm{m}$.

(Fig. 5a). When $0.1 \mathrm{nmol}$ oestradiol $\mathrm{l}^{-1}$ was used, DNA content decreased by $11.8 \%$, but was not statistically different from the control. However, when increased concentrations of oestradiol ( 1 and $10 \mathrm{nmol} \mathrm{l}^{-1}$ ) were used, the inhibitory effect of oestradiol on epithelial proliferation was significant $(27.9 \%$ and $34.5 \%$, respectively, $P<0.001$ ). In contrast, progesterone had no significant effect on the proliferation of epithelial cells, but did block the inhibitory effect of oestradiol on epithelial proliferation.

The changes in total protein content of endometrial epithelial cells measured at day 4 (Fig. 5 b) were similar to those observed for the DNA content. The total protein contents for the various concentrations of oestradiol $\left(0.1,1,10 \mathrm{nmol} \mathrm{I}^{-1}\right.$ ) were $15.9 \%, 28.8 \%$, and $36 \%$ lower than that of the control $(P<0.05)$. Progesterone alone or progesterone plus oestradiol had no significant effect on total protein content.

The results of the ANOVA for DNA content, protein content and the ratio of protein to DNA showed that the effects of hormone treatments, duration of culture, and the interaction between treatments and duration were significant $(P<0.01)$ (Fig. 6). The DNA content did not change between days 4 and 8 in the epithelial cells treated with oestradiol $\left(1 \mathrm{nmol} \mathrm{I}^{-1}\right)$ or progesterone $\left(50 \mathrm{nmol} \mathrm{l}^{-1}\right)$ plus oestradiol ( $1 \mathrm{nmol} \mathrm{l^{-1 }}$ ) $(P>0.05)$ (Fig. 6a). Thus, there was no obvious cell proliferation in the presence of 1 nmol oestradiol $1^{-1}$ during this time. However, the DNA content increased $46.7 \%$ in the control and $45.3 \%$ in the presence of progesterone alone $\left(50 \mathrm{nmol} \mathrm{l}^{-1}\right)(P<0.01)$. Also, after more prolonged culture
( 8 days), progesterone was not able to prevent the inhibitory effect of oestradiol on proliferation of epithelial cells. Therefore, the effect of oestradiol and progesterone on epithelial proliferation was time dependent.

After 8 days of incubation, total protein content in epithelial cells was increased by progesterone $\left(50 \mathrm{nmol} \mathrm{I}^{-1}\right)$ and progesterone plus oestradiol $(19.9 \%, 17.3 \%$, respectively, over control, $P<0.01$ ) and the inhibitory effect of oestradiol ( $1 \mathrm{nmol}$ $\mathrm{l}^{-1}$ ) was not observed (Fig. 6b). After 4 days of incubation there was no effect of treatment on the protein: DNA ratio (Fig. 6c). However, after 8 days of incubation, this ratio was increased significantly by the presence of oestradiol ( $\mathrm{I}$ nmol $\left.1^{-1}\right)$, either alone, or in combination with progesterone (Fig. 6c). This result indicates that even though oestradiol inhibited DNA synthesis in endometrial epithelial cells, it did not inhibit protein synthesis, and even stimulated protein synthesis with time.

\section{Discussion}

In the present report, a method is described for studying the effects of progesterone and oestradiol on the proliferation and morphology of bovine uterine endometrial epithelial and stromal cells using an in vitro primary cell culture system. The purification procedures used resulted in a homogeneous stromal cell population with very little epithelial cell 

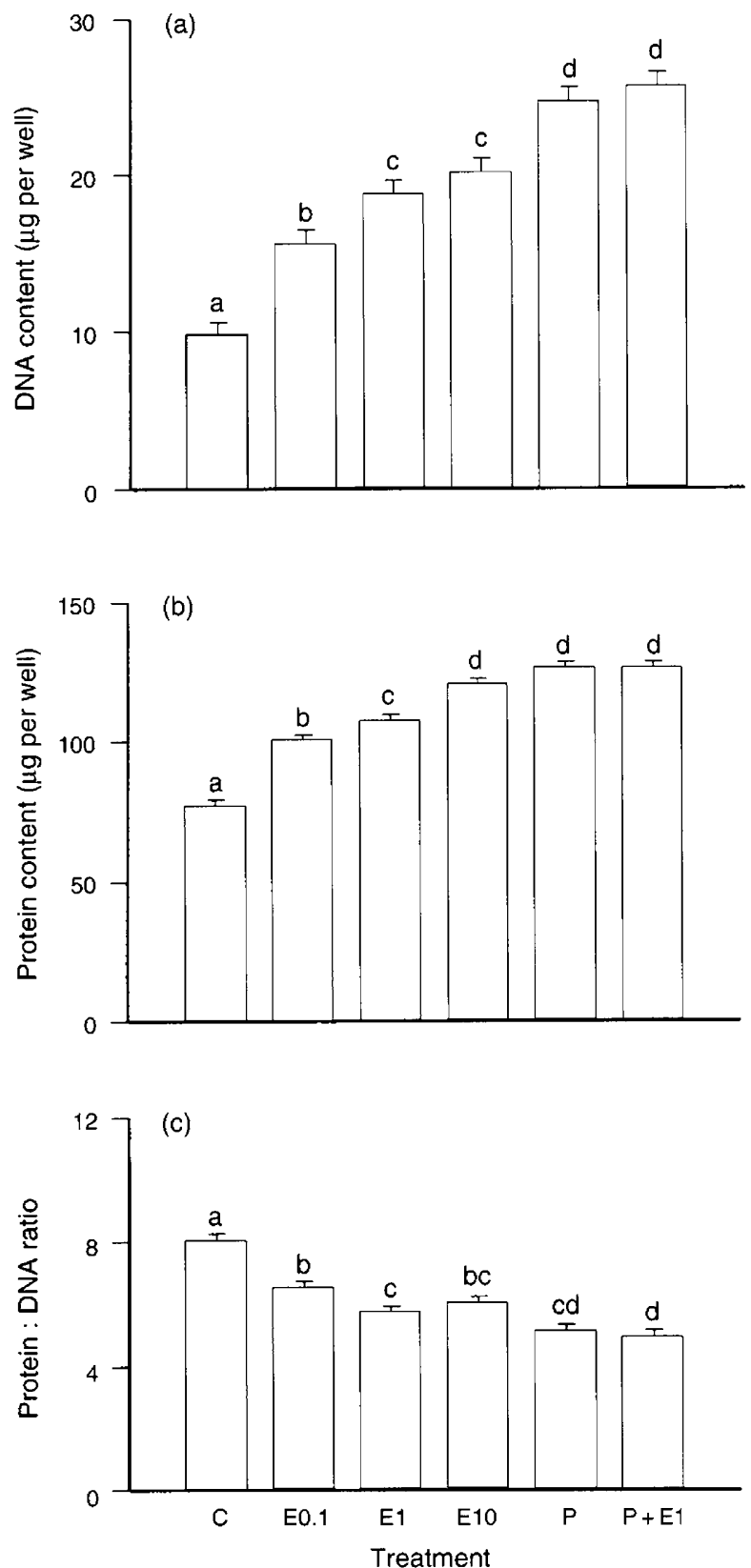

Fig. 3. Effects of oestradiol and progesterone on (a) DNA content, (b) protein content and (c) the ratio of protein to DNA in bovine endometrial stromal cells. Primary bovine endometrial stromal cells were cultured with RPMI medium supplemented with $5 \%$ steroid-free fetal calf serum in the absence (C) or presence of various doses of oestradiol (E0.1: $0.1 \mathrm{nmol} \mathrm{l}^{-1}$; EI: $1 \mathrm{nmol} \mathrm{l}^{-1}$; E10: $10 \mathrm{nmol} \mathrm{l}^{-1}$ ) or progesterone ( $\mathrm{P}$ : $50 \mathrm{nmol} 1^{-1}$ ) or oestradiol plus progesterone $\left(\mathrm{P}+\mathrm{EI}\right.$ : $1 \mathrm{nmol}$ oestradiol $\mathrm{l}^{-1}$ plus $50 \mathrm{nmol}$ progesterone $\left.\mathrm{l}^{-\mathrm{I}}\right)$ for 4 days. Data represent least-square means \pm SEM. Bars with different letters are significantly different $(P<0.01)$.

contamination. Stromal cell contamination of the epithelial cells was approximately $3 \%$. The effects of oestradiol on bovine endometrial cell proliferation have been shown for the first time using this system.

Oestradiol did not significantly change the morphology of either cell type. However, progesterone, either alone or in
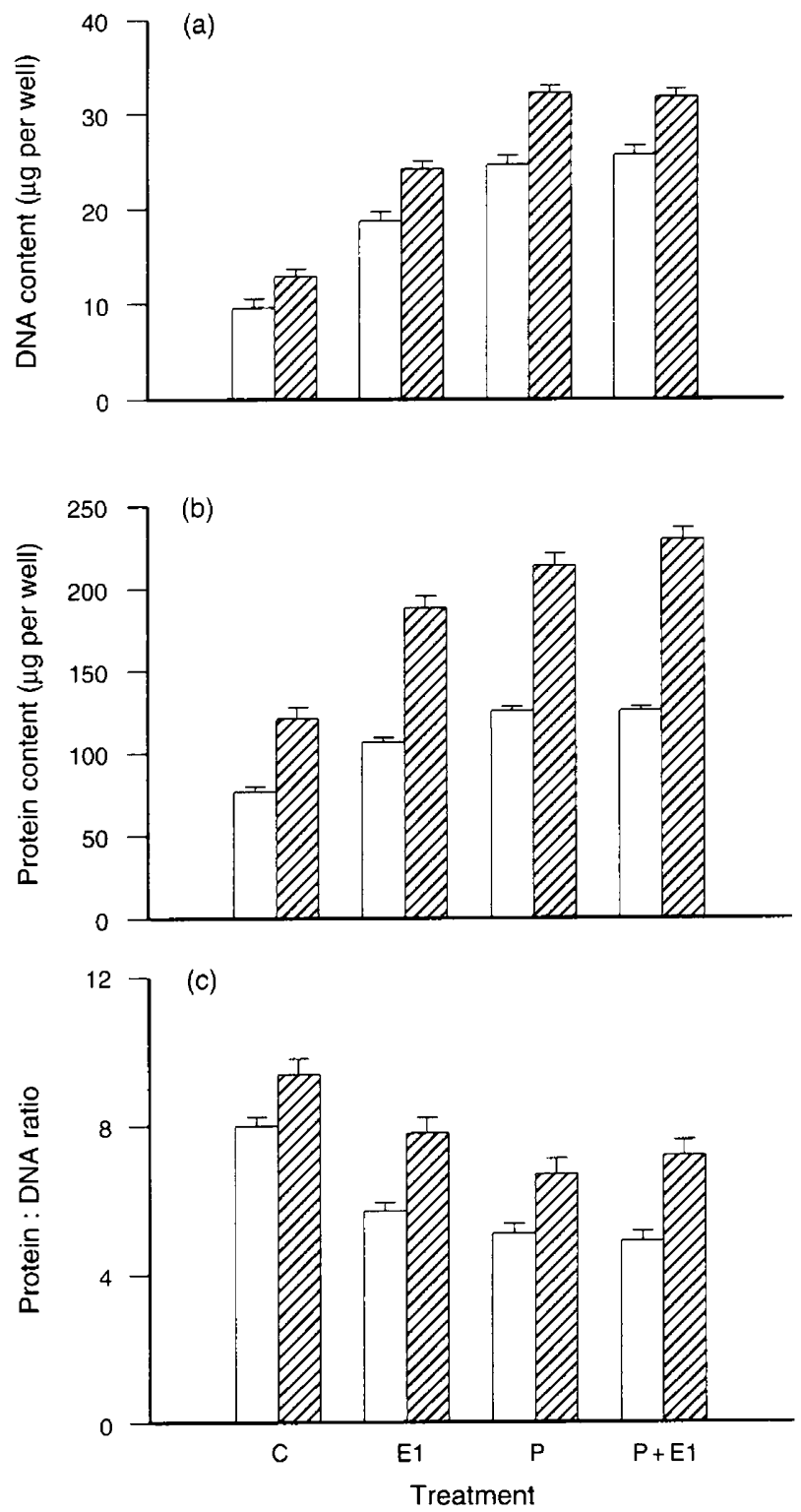

Fig. 4. Time-dependent effect of oestradiol and progesterone on (a) DNA content (b) protein content and (c) ratio of protein to DNA in bovine endometrial stromal cells. Primary bovine endometrial stromal cells were cultured with RPMI medium supplemented with 5\% steroid-free fetal calf serum in the absence $(C)$ or presence of either oestradiol (EI: $1 \mathrm{nmol} \mathrm{I}^{-1}$ ), or progesterone (P: $50 \mathrm{nmol} \mathrm{I}^{-1}$ ), or oestradiol plus progesterone (P+E1: $1 \mathrm{nmol}$ oestradiol $\mathrm{I}^{-1}$ plus $50 \mathrm{nmol}$ progesterone $\mathrm{I}^{-1}$ ) for 4 days ( $\square$ ) or 8 days $(\bigotimes)$. Data represent least-square means \pm SEM.

combination with oestradiol, altered the morphology of stromal, but not epithelial cells. Significant changes in the morphology of cultured uterine stromal cells, induced by the addition of ovarian steroids or progesterone, have been observed in humans (Gurpide and Holinka, 1987; Holinka, 1988), and it has been suggested that progestins may affect cytoskeletal proteins (Gurpide and Holinka, 1987).

Nuclear incorporation of $\left[{ }^{3} \mathrm{H}\right]$ thymidine is a conventional and widely used measurement of DNA synthesis and cell proliferation. However, some discrepancies between 

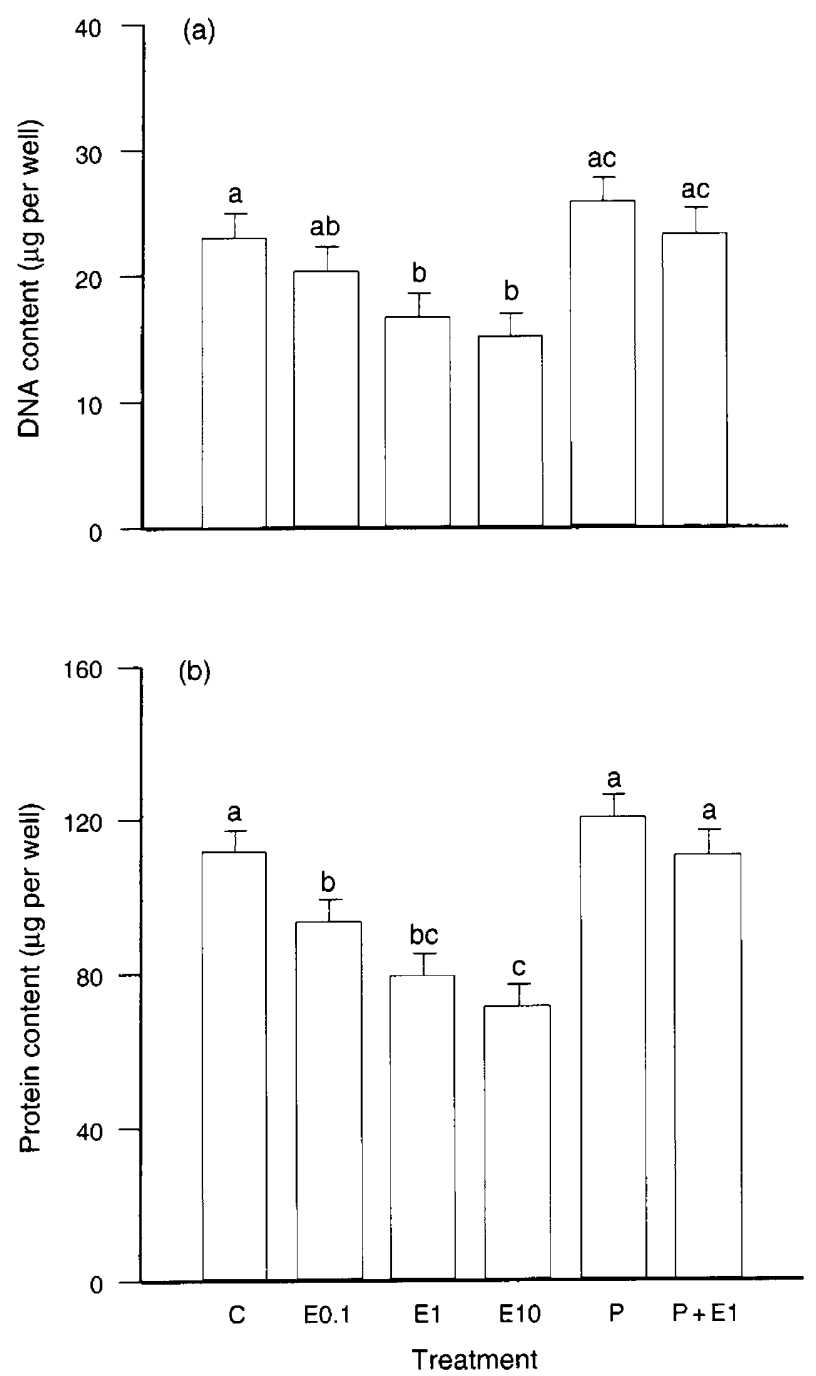

Fig. 5. Effects of oestradiol and progesterone on (a) DNA content and (b) protein content in bovine endometrial epithelial cells. Primary bovine endometrial epithelial cells were cultured with RPMI medium supplemented with $5 \%$ steroid-free fetal calf serum in the absence or presence of various doses of oestradiol (E0.1: $0.1 \mathrm{nmol}^{-1}$; EI: $1 \mathrm{nmol}$ $\mathrm{I}^{-1} ; \mathrm{E} 10: 10 \mathrm{nmol} \mathrm{I}^{-1}$ ) or progesterone (P: $50 \mathrm{nmol} \mathrm{I}^{-1}$ ) or oestradiol plus progesterone $\left(P+E 1: 1\right.$ nmol oestradiol $l^{-1}$ plus $50 \mathrm{nmol}$ progesterone $1^{-4}$ ) for 4 days. Data represent least-square means \pm SEM. Bars with different letters are significantly different $(P<0.01)$.

$\left.{ }^{3} \mathrm{H}\right]$ thymidine incorporation and true cell proliferation have been reported (Friedman et al., 1981; Jozan et al., 1983, 1985). Jozan et al. (1983) noted increased incorporation of $\left[{ }^{3} \mathrm{H}\right]$ thymidine after oestradiol treatment, but no change in the number of cells, no increase of the size of nuclei, and no increase in DNA content. This discrepancy was also shown in primary cultures of rat hepatocytes that incorporated $\left[^{3} \mathrm{H}\right]$ thymidine but did not divide (Friedman et al, 1981). The explanation for this discrepancy is that the addition of $\left[{ }^{3} \mathrm{H}\right]$ thymidine during a short period of time could miss the $S$ phase of DNA synthesis. If the incubation time was extended, there would be more time for the cell to degrade labelled thymidine and to spread the label in its general metabolism (Murat et al., 1990). The direct measurement of DNA content
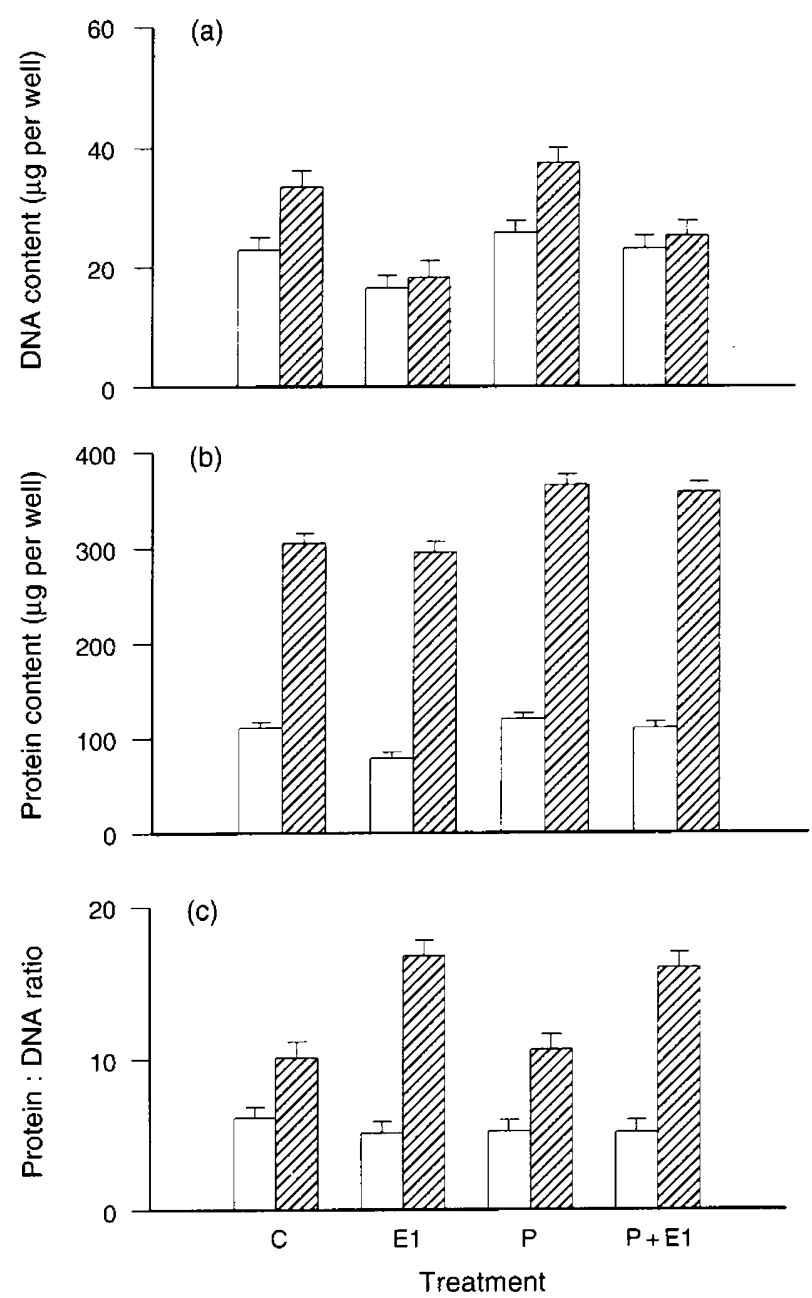

Fig. 6. Time-dependent effect of oestradiol and progesterone on (a) DNA content (b) protein content and (c) ratio of protein to DNA in bovine endometrial epithelial cells. Primary bovine endometrial epithelial cells were cultured with RPMI medium supplemented with $5 \%$ steroid-free fetal calf serum in the absence $(C)$ or presence of either oestradiol (EI: $1 \mathrm{nmol} \mathrm{I}^{-1}$ ), or progesterone $\left(\mathrm{P}: 50 \mathrm{nmol} \mathrm{l}^{-1}\right.$ ), or oestradiol plus progesterone (P+EI: 1 nmol oestradiol $\mathrm{l}^{-1}$ plus $50 \mathrm{nmol}$ progesterone $\mathrm{I}^{-1}$ ) for 4 days $(\square)$ or 8 days $(\square)$. Data represent least-square means \pm SEM.

used in the present study is highly correlated with cell number $\left(r^{2}=0.999\right)$, which is consistent with a previous report (Inaba et al, 1988), and therefore, should be a better indication of cell proliferation. However, even with the use of DNA and protein measurement, the possibility that treatment of the cells affects cell viability cannot be eliminated.

In vivo, oestradiol causes hypertrophy and hyperplasia of the endometrium and progesterone is thought to act on an oestradiol-primed uterus to stimulate growth of the endometrium. Progesterone is known to modify the action of oestrogen on the uterus by redirecting the proliferative response from the epithelium to the stroma. Martin and Finn (1969) reported that oestradiol stimulated the proliferation of the luminal epithelial cells, but not the stromal cells in mice uteri. However, after pretreatment with progesterone, oestradiol stimulated mitosis in the stroma, but not in the epithelium. 
Recent results in sheep have shown that highest rates of cell proliferation occur at the beginning of the oestrous cycle, with proliferation being greater in the luminal epithelium and glands than in the stroma (Johnson et al., 1997). In ovariectomized sheep, oestradiol stimulates proliferation in the epithelium and stroma, whereas progesterone predominantly stimulates the proliferation of epithelial cells Johnson et al., 1994).

In the present study, the proliferation of bovine endometrial stromal cells was stimulated by oestradiol and progesterone, either alone or in combination. Similar effects have been reported for oestradiol and progesterone on the proliferation of human endometrial stromal cells (Irwin et al., 1991; Chegini et al., 1992). The observed stimulation by oestradiol is also consistent with the effect of oestradiol on ovariectomized sheep (Johnson et al, 1997). However, progesterone had little effect in the ovariectomized sheep in that study, whereas, in the present study, it stimulated stromal cell proliferation in vitro. Therefore, it is possible that the response to progesterone in vivo is modified by the epithelial cells. The present results differ from previously published data on the effects of steroids on bovine endometrial cells. Tiemann et al. (1994) found that oestradiol and progesterone were ineffective in stimulating $\left[{ }^{3} \mathrm{H}\right]$ thymidine incorporation by epithelial and stromal cells in a serum-free medium. Asselin and Fortier (1996) recently reported that oestradiol had no effect on cell proliferation, while progesterone inhibited $\left[{ }^{3} \mathrm{H}\right]$ thymidine incorporation in cultured bovine epithelial and stromal cells. There are three possible explanations for these differences: ( 1 ) as explained above, thymidine incorporation may give different results to DNA or protein measurement. (2) In the study of Tiemann et al. (1994), cells were isolated from the uterus at the mid-luteal phase, whereas in the present study, cells were isolated early in the cycle. Thus, the stage of the cycle at which the samples were taken could affect the response in vitro. There is evidence to support this suggestion. In sheep, proliferation of both the epithelial and stromal cells is greatest at the beginning of the cycle (Johnson et al., 1997). Oestradiol stimulates the proliferation of stromal cells in immature rodents (Eide, 1975; Kirkland et al, 1979; Pollard, 1990), but not in adult rats and mice (Quarmby and Korach, 1984; Pollard, 1990). Fleming and Gurpide (1982) also demonstrated that human endometrial stromal cells, obtained at different phases of the oestrous cycle, grow differently in culture. There is clear evidence of cyclical changes in the expression of steroid receptors in endometrial tissue (Bergqvist, 1991; Prentice et al., 1992). Thus, the time that tissue samples are taken might result in differences in the expression of steroid and epidermal growth factor receptors (Mellor and Thomas, 1994) and alter the response in vitro. (3) Serum or growth factors may be necessary for oestradiol to exert its effect. The ineffectiveness of oestradiol on the proliferation of stromal cells (Fleming and Gurpide, 1982; Mellor and Thomas, 1994; Tiemann et al., 1994; Asselin and Fortier, 1996) could be due to a lack of unknown serum factors or growth factors required for cultured cells to respond to oestrogen stimulation (Kano-Sueoka et al., 1979; Page et al., 1983; Irwin et al., 1991; Tiemann et al., 1994). The medium used in this study was supplemented with 5\% FCS to provide the required serum factors or growth factors. The choice of $5 \%$ FCS was based on the consideration that higher concen- trations of serum may mask any effects of treatment since cell proliferation increases as serum concentration in the medium increases.

Oestradiol and progesterone increased the total protein content of stromal cells. However, the ratios of protein to DNA were significantly decreased by treatment with oestradiol and progesterone for 4 days. It is possible that the cells became multi-nucleated (this was not examined). These results do agree with a previous study in rats (McCormack, 1980), which demonstrated that the ratios of protein to DNA in stromal cells remained unchanged for $12 \mathrm{~h}$ after an injection of oestradiol, and then decreased significantly by $24 \mathrm{~h}$. In addition, in sheep, the ratio of protein to DNA decreases at mid-cycle suggesting an in vivo effect of steroid hormones (Johnson et al., 1997).

Oestradiol alone inhibited proliferation in epithelial cells in a dose-dependent manner, and the addition of progesterone prevented this inhibitory effect of oestradiol. In mouse epithelial cells (Huet-Hudson et al, 1989), c-myc induction and enhanced proliferation are oestradiol-dependent and in sheep, oestradiol stimulates the proliferation of the luminal epithelium (Johnson et al., 1994). However, Marshburn et al. (1994) showed that DNA synthesis in cultured human endometrial epithelial glands was decreased by $40 \%$ after treatment with oestradiol $\left(1 \times 10^{-8} \mathrm{~mol} \mathrm{l}^{-1}\right)$ for 5 days. A similar inhibitory effect of oestradiol on DNA synthesis was also observed by Alkhalaf et al. (1991) in the endometrial epithelial cells of guinea-pigs. The inhibitory effect of oestradiol on epithelial cell proliferation may be due to the lack of stromal-epithelial interaction. Stroma can mediate the hormonal responsiveness of epithelial cells in humans (Brenner et al., 1990) and mice (Inaba et al., 1988; Haslam and Counterman, 1991) and a paracrine interaction between stromal and epithelial cells may be required before an increase in proliferation in response to oestradiol will occur (Cunha et al., 1983).

The ratios of protein to DNA of epithelial cells remained unchanged for 4 days after treatment with oestradiol and progesterone. However, oestradiol significantly increased the ratios in epithelial cells after 8 days of treatment to much higher values than in stromal cells. Smith et al. (1970) demonstrated that oestradiol enhances protein synthesis in the epithelial cells of adult mice, and that protein synthesis was higher in epithelial cells than in stromal cells. However, McCormack and Glasser (1980) showed that oestradiol administration did not significantly change the ratios of protein to DNA in rat epithelial cells.

In conclusion, progesterone altered the morphology of stromal cells, but not of epithelial cells. The present study demonstrates for the first time that both oestradiol and progesterone can enhance the proliferation of bovine stromal cells. Oestradiol inhibited the growth of epithelial cells in a dose-dependent manner, while progesterone appeared to have no effect on the proliferation of epithelial cells. Oestradiol and progesterone decreased the ratios of protein to DNA in stromal cells, whereas oestradiol enhanced the ratios in epithelial cells. Stromal cells were more responsive to steroids than epithelial cells. It is possible that an interaction between stromal and epithelial cells is necessary for the normal response of epithelial cells in vivo. 
This work was supported by grants from NSERC and FCAR Canada.

\section{References}

Alkhalaf M, Mahfoudi A, Propper AY and Adessi GL (1991) Additive effect of oestradiol-17 $\beta$ and serum on synthesis of deoxyribonucleic acid in guineapig endometrial cells in culture Journal of Reproduction and Fertility 93 295-302

Asselin E and Fortier MA (1996) Influence of thrombin on proliferation and prostaglandin production in cultured bovine endometrial cells Journal of Cellular Physiology 168 600-607

Asselin E, Goff AK, Bergeron H and Fortier MA (1996) Influence of sex steroids on the production of prostaglandins $F 2 \alpha$ and $E 2$ and response to oxytocin in cultured epithelial and stromal cells of the bovine endometrium Biology of Reproduction $54371-379$

Bergeron H and Goff AK (1993) Effects of progesterone and estradiol on oxytocin stimulation of prostaglandin F2 $\alpha$ release by stromal and epithelial cells of bovine endometrium Biology of Reproduction 48 (Supplement I) 226 (Abstract)

Bergqvist A (1991) Steroid receptors in endometriosis. In Modern Approaches to Endometriosis pp 33-55. Eds EJ Thomas and J Rock. Kluwer Academic Publishers, Dordrecht, Holland

Brenner RM, West NB and McClellen MC (1990) Oestrogen and progestin receptors in the reproductive tract of male and female primates Biology of Reproduction 42 11-19

Chegini N, Rossi MJ and Masterson BJ (1992) Platelet-derived growth factor (PDGF), epidermal growth factor (EGF), and EGF and PDGF $\beta$-receptors in human endometrial tissue: localization and in vitro action Endocrinology 130 2373-2385

Conti CJ, Gimenez-Conti IB, Zerbe GO and Gerschenson LE (1981) Differential effects of estradiol-17 $\beta$ and progesterone on the proliferation of glandular and luminal cells of rabbit uterine epithelium Biology of Reproduction 24 643-648

Cunha GR, Chung JM, Taguchi D and Fujii H (1983) Hormone-induced morphogenesis and growth: role of mesenchymal-epithelial interation Recent Progress in Hormone Research 39 559-598

Di Augustine RP, Petrusz P, Bell GI, Brown CF, Korach KS, McLachlan JA and Teng CT (1988) Influence of estrogens on mouse uterine epidermal growth factor precursor protein and messenger ribonucleic acid Endocrinology 122 2355-2363

Eide A (1975) The effect of oestradiol on the DNA synthesis in neonatal mouse uterus and cervix Cell Tissue Research 156551

Fleming $\mathrm{H}$ and Gurpide E (1982) Growth characteristics of primary cultures of stromal cells from human endometrium Journal of Steroid Biochemistry 16 $717-720$

Fortier MA, Guibault LA and Grasso F (1988) Specific properties of epithelial and stromal cells from the endometrium of cows Journal of Reproduction and Fertility $83 \quad 239-248$

Friedman DL, Claaus TH, Pilkis SJ and Pine GE (1981) Hormonal regulation of DNA synthesis in primary culture of adult rat hepatocytes Experimental $C_{e l l}$ Research 135 283-290

Gurpide E and Holinka CF (1987) Proliferative potential and polymorphism of human endometrial stromal cells Gynecological Endocrinology 1 71-81

Haslam SZ and Counterman LJ (1991) Mammary stroma modulates hormonal responsiveness of mammary epithelium in vivo in the mouse Endocrinology 129 2017-2023

Holinka CF (1988) Growth and hormonal responsiveness of human endometrial stromal cells in culture Human cell 1 207-217

Huet-Hudson YM, Andrews GK and Dey SK (1989) Cell type-specific localization of $c-m y c$ protein in the mouse uterus: modulation by steroid hormones and analysis of preimplantation period Endocrinology 125 1683-1690

Iguchi T, Uchima FDA, Ostrander PL and Bern HA (1983) Growth of normal mouse vaginal epithelial cells in and on collagen gels Proceedings of the National Academy of Sciences of USA $803743-3747$

Inaba T, Wiest WG, Strickler RC and Mori J (1988) Augmentation of the response of mouse uterine epithelial cells to estradiol by uterine stroma Endocrinology $123 \quad 1253-1258$

Irwin JC, Kirk D, King RJB, Quigley MM and Gwatkin RBL (1989) Hormonal regulation of human endometrial stromal cells in culture: an in vitro model for decidualization Fertility and Sterility 52 761-768
Irwin JC, Utian WH and Eckert RL (1991) Sex steroids and growth factors differentially regulate the growth and differentiation of cultured human endometrial stromal cells Endocrinology 129 2385-2392

Johnson DA, Redmer DA and Reynolds LP (1994) Histological evaluation of cell proliferation in the uterus of intact and steroid-treated ovariectomized (OVX) ewes Journal of Animal Science 72 (Supplement 2) 74 (Abstract)

Johnson ML, Radmer DA and Reynolds LP (1997) Uterine growth, cell proliferation, and c-fos proto-oncogene expression throughout the estrous cycle in ewes Biology of Reproduction 56 393-401

Jozan S, Mirouze A, Gay AG, Marques B and David JF (1983) Estradiol and ${ }^{3} \mathrm{H}$-thymidine incorporation in cultured human cancer cells (breastendometrium) Bulletin de L'Association des Anatomistes 67 193-197

Jozan S, Gay G, Marques B, Mirouze A and David JF (1985) Oestradiol is effective in stimulating ${ }^{3} \mathrm{H}$-thymidine incorporation but not on proliferation of breast cancer cultured cells Cell and Tissue Kinetics 18 457-464

Kano-Sueoka T, Errick JE and Cohen DM (1979). Effects of hormones and a novel mammary growth factor on a rat-mammary carcinoma in culture. In Hormone and Cell Culture pp 449-512. Eds GH Sato and R Ross. Cold Spring Harbor, New York

Kirkland JL, LaPointe L, Justin E and Stancel GM (1979) Effect of estrogen on mitosis in individual cell types of the immature rat uterus Biology of Reproduction 21269

Labarca C and Paigen K (1980) A simple, rapid and sensitive DNA assay procedure Analytical Biochemistry 102 344-352

Lafrance M and Goff AK (1988) Effects of progesterone and oestradiol-17 $\beta$ on oxytocin-induced release of prostaglandin $\mathrm{F} 2 \alpha$ Journal of Reproduction and Fertility 82 429-436

McCormack SA and Glasser SR (1980) Differential response of individual uterine cell types from immature rats treated with estradiol Endocrinology 106 1634-1649

McCracken JA, Schramm W and Okulicz WC (1984) Hormone receptor control of pulsatile secretion of PGF $2 \alpha$ from the ovine uterus during luteolysis and its abrogation in early pregnancy Animal Reproduction Science 7 31-55

Marshburn PB, Arici AM and Casey ML (1994) Expression of transforming growth factor- $\beta 1$ messenger ribonucleic acid and the modulation of deoxyribonucleic acid synthesis by transforming growth factor- $\beta 1$ in human endometrial cells American Joumal of Obstetrics and Gynecology $1701152-$ 1158

Martin L and Finn CA (1969) Duration of progesterone treatment required for a stromal response to oestradiol- $17 \beta$ in the uterus of the mouse Journal of Endocrinology 44 279-280

Mellor SJ and Thomas EJ (1994) The actions of estradiol and epidermal growth factor in endometrial and endometriotic stroma in vitro. Fertility and Sterility 62 507-513

Mukku LJ and Stancel GM (1985) Regulation of epidermal growth factor receptor by estrogen Journal of Biological Chemistry 2609820-9824 ..

Murat JC, Gamet L, Cazenave Y and Trocheris V (1990) Questions about the use of ${ }^{3} \mathrm{H}$-thymidine incorporation as a reliable method to estimate cell proliferation rate Biochemical Journal 270 563-564

Murphy LJ, Murphy LC and Friesen HG (1987) Estrogen induces insulin-like growth factor 1 expression in the rat uterus Molecular Endocrinology 1 $445-450$

Nalbandov AV (1976) Reproductive physiology of mammals and birds. In Reproductive Physiology of Mammals and Birds pp 126-156. Ed. SG Salisbury. WH Freeman and Company, San Francisco

Page MJ, Field JK, Everett NP and Green CD (1983) Serum regulation of the estrogen responsiveness of the human breast cancer cell line MCF-7 Cancer Research 43 1244-1250

Pavlik EJ and Katzenellenbogen BS (1978) Human endometrial cells in primary tissue culture: estrogen interactions and modulation of cell proliferation Journal of Clinical Endocrinology and Metabolism $47333-344$

Pollard JW (1990) Regulation of polypeptide growth factor synthesis and growth factor-related gene expression in the rat and mouse uterus before and after implantation Journal of Reproduction and Fertility $\mathbf{8 8}$ $721-731$

Prentice A, Randall BJ, Weddell A, McGill A, Henry L and Horne CHW (1992) Ovarian steroid receptor expression in endometriosis and in two potential parent epithelia: endometrium and peritoneal mesothelium Human Reproduction 7 1318-1325

Quarmby VE and Korach KS (1984) The influence of $17 \beta$-estradiol on patterns of cell division in the uterus Endocrinology 114 694-702 
Rossi MJ, Chegini N and Masterson BJ (1992) Presence of epidermal growth factor, platelet-derived growth factor, and their receptors in human myometrial tissue and smooth muscle cells: their action in smooth muscle cells in vitro. Endocrinology 30 1716-1727

Smith JA, Martin L, King RJB and Vértes M (1970) Effects of oestradiol-17 $\beta$ and progesterone on total and nuclear-protein synthesis in epithelial and stromal tissues of the mouse uterus, and of progesterone on the ability of these tissues to bind oestradiol-17 $\beta$ Biochemical Journal $119773-784$

Tiemann U, Schneider F, Tuchscherer A and Becker F (1994) Influence of epidermal growth factor and steroids on the proliferation of cultured uterine cells in bovine treated with different gonadotropins Reproduction in Domestic Animals 29 513-524
Tomooka DRP and McLachlan JA (1986) Proliferation of mouse uterine epithelial cells in vitro. Endocrinology 118 1011-1018

Van der Burg GR, Blankenstein MA, Delaat SW and Van Zoelen EJJ (1988) Mitogenic stimulation of human breast cancer cells in a growth defined medium Journal of Cell Physiology 134 101-108

Watson H, Franks S and Bonney RC (1994) Regulation of epidermal growth factor receptor (EGFR) by oestradiol and progesterone in human endometrial stromal cells Journal of Endocrinology 140231

Wilmut I, Sales DI and Ashworth CJ (1985) The influence of variation in embryo stage and maternal hormone profiles on embryo survival in farm animals Theriogenology 23 107-119 